\title{
Web Based Incoming and Outgoing Mail Management Information System with CodeIgniter Framework
}

\author{
Fitri Siti Nurjanah ${ }^{1}$, Yuda Permana ${ }^{2}$, Falaah Abdussalaam ${ }^{3}$, Jaenal Arifin $^{4}$ \\ 1,2,3,4 Informatics Management Study Program, Piksi Ganesha Polytechnic \\ (J1. Jend. Gatot Subroto 301, Bandung 40274, Indonesia) \\ e-mail: ${ }^{1}$ fsnurjanah@ piksi.ac.id, ${ }^{2}$ ypermana@ piksi.ac.id ${ }^{3}$ falaahabdussalaam@gmail.com, \\ jaenal.arifin@piksi.ac.id
}

\begin{abstract}
Rancaekek District still uses Mail as a means of communicating both to the community and other agencies. Every day many incoming and outgoing Mail are managed by the Rancaekek District so that there is a buildup of Mail, the management of Mail that still use manuals is certainly not effective where Mail will only be written in a ledger and then stored in a filing cabinet. This ineffectiveness certainly makes difficult for users when looking for the required letter sheets from this problem. Of course, Rancaekek District needs a computerized design of an information system for managing incoming and outgoing mail, making it easier to search for Mail, minimizing the occurrence of lost Mail and managing correspondence administration to be more effective, and efficient. The design of this information system uses on object-oriented approach with UML (Unified Modeling Language) capital implemented with PHP programming language (PHP: Hypertext Pre-processor) and uses MYSQL database and CodeIgniter Framework. The method used in the design of this information system is the waterfall. Based on the Blackbox testing information system testing, the designed features include managing incoming and outgoing mail and managing reports, can run well, such as inputting, using databases as storage media, managing letter categories based on the total number of incoming and outgoing Mail, number of Mail per day, and number of Mail per year displayed in graphic form In addition, the reporting system which is categorized by division has made it easier for users to submit letter reports and according to what is needed.
\end{abstract}

Keywords: Information System, Mail management, CodeIgniter, PHP, MYSQL

\section{Introduction}

Rancaekek District is in the eastern part of Bandung Regency, which is one of 31 Districts in Bandung Regency, West Java Province. Rancaekek sub-district houses 14 (fourteen) villages including (Bojongloa Village, Bojongsalam Village, Cangkuang Village, Haurpugur Village, Jelegong Village, Linggar Village, Nanjungmekar Village, Rancaekek Kulon Village, Rancaekek Wetan Village, Sangiang Village, Sukamanah Village, Sukamulya Village, Tegal Sumedang Village and Rancaekek Kencana Village) [1].

Advances in technology and communication science make this world feel more and more narrow, the system is directed to be fast and precise, the implementation process no longer takes a long time, administration is carried out computerized, mail management procedures are a source that can be useful for agencies or organizations, as it develops. increasingly sophisticated communication tools, telephones and gadgets have become one of the liaisons in various circles, but it is undeniable that there are still communication tools that cannot be replaced by time, namely Mail [2]. Mail are still used as a means of information and communication, in the general and staffing department in Rancaekek District, which is in charge of taking care of administrative activities, both outgoing and incoming Mail. Outgoing letter is a letter issued or made by the District of Rancaekek which is addressed to individuals/agencies/organizations within and outside the District of Rancaekek. While the incoming letter is a letter received by the kelurahan from individuals/agencies/organizations located outside the kelurahan of Rancaekek [3]. 
The management of Mail carried out by the Rancaekek sub-district includes the opening of Mail, whether Mail received through delivery media such as the post office or Mail given directly to employees on duty, writing Mail on disposition sheets, grouping Mail by month and year. Record the Mail in a large agenda book. archiving to distribution is done in the general and personnel department.

In carrying out its government duties as regional autonomy, Rancaekek Regency uses Mail as a means of communication and information to the public and agencies. The management of the distribution of Mail carried out in Rancaekek District still uses manuals where every incoming and outgoing letter will be written on a large agenda book, then the sheet will be copied and will be given to the leadership after the sheet is given back by the leadership, the staff will write the Mail automatically. manual, then the staff will dispose of the letter based on the date of the letter, the purpose of the letter, and the importance of the letter, then the letter will be distributed to the intended division and will return to the general and staffing section to be used as an archive. each sheet of letter will be stacked on a folder each letter per month which will then be stored in a filing cabinet. Manual mail management certainly has many shortcomings, such as Mail not being archived properly, damaged Mail, and lost Mail [4].

This research is purely from the observations of researchers as well as references from previous researchers, previous research references become references in research and writing as for the research including.

Research conducted by Ahmad Nauvel, Sutrisno, Rizkika Indriani by title Sistem Informasi Surat Masuk dan Surat Keluar pada Suatu Instansi [5]. They used the waterfall system development and came to the conclusion that with the information system it can save time in searching for incoming and outgoing mail, save on shipping costs because it is done online, and make filing easier.

In 2016 Anggi Darlianto dan Inggih Permana conducted a study entitled Sistem Informasi Pencatatan Surat Masuk Pada Kantor Camat di Kecamatan Kampar kiri Kabupaten Kampar Provinsi Riau [6]. They produce features of incoming mail, disposition, and reporting and conclude by analyzing system requirements such as incoming mail management, outgoing mail management, agenda bookkeeping, with this system it is hoped that there will be no more problems in mail management.

Sistem informasi Pengarsipan Surat Masuk dan Surat Keluar Berbasis Web di Kecamatan Batujajar [7]. This design uses MVC (Model, View, Controller) mode and uses the PHP programming language. They focus on mail filing and positioning systems so there is no more loss of mail data.

The latest research that is relevant to this research is Pengelolaan Surat Masuk dan Surat Keluar di Kecamatan Ngapak Yogyakarta [8]. This research resulted in a complex system, the system can process incoming mail, deposition and outgoing mail, registration and access rights for each division.

From some of these studies, it can be concluded that the creation of a mail management information system has been studied a lot and has produced a system that is more effective and efficient so that it can facilitate its management. But many of these research researchers see that they only have some features and have no other features.

The solution offered by the researcher is based on the background and references from previous studies, in searching for data and comparing the research that the researcher did with the previous researchers, the researcher found that previous research only focused on storing Mail, in this study the researcher will continue research based on these references by adding features. Of course the Rancaekek District needs an information system that aims to facilitate mail management and become more effective and efficient, so in this study the Design of WebBased Incoming and Outgoing Mail Management Information Systems with CodeIgniter Framework. An information system is needed so that archive information in Mail can be managed properly, access rights for each user are limited to more points so that not just anyone can access the information, access rights are only given to officers in charge of Rancaekek District such as the Camat and archive staff. For each functional staff in each division can only 
access some features in the information system. Such as notification and writing and reporting of outgoing mail. Without having access to write incoming Mail, because this is the right of access for archival staff in the general environment and personnel so that there is no difference in perception between one division and access staff.

\section{Research Methods}

In this study, the author uses a qualitative research method with a descriptive approach. According to Sugiono, the type of qualitative research is research that understands an event based on the participant's point of view [9]. According to Kriyantono, qualitative aims to explain an event by looking for as much data as possible, collecting as much data as possible, so that the more and detailed data obtained, the better the research conducted. [10]

To obtain relevant and transparent data in order to facilitate and expedite this research, the authors carry out several stages of data collection methods including:

a. Observation

Observation carried out directly observing and studying the state of the research object located in Rancaekek District, Bandung Regency

b. Interview

Interviews were conducted with resource persons who were directly related to the administrative process of correspondence in Rancaekek District by discussing in order to obtain accurate information and in accordance with the required data.

c. Study of literature

Literature studies are used to obtain more relevant information and to complete the data requirements needed and used as comparisons in writing, heritage studies are carried out by reading and reviewing the operational procedures for managing incoming and outgoing mail which are available in books and other scientific journals related to this study material [11].

\subsection{Development Method}

The development method used in the design of this system is the waterfall method or the fountain method, the structure of this method makes it a common and widely used method. This development method is the author's reference in determining the steps in the research. The Waterfall method is a conceptual and systematic system development, in this method everything must be done sequentially, cannot complete the design when it has not done the requirements, all things that will be done must be in order from the start of requirements, design, implementation, verification, and maintenance of it of course in order to minimize the occurrence of errors that may occur [12].

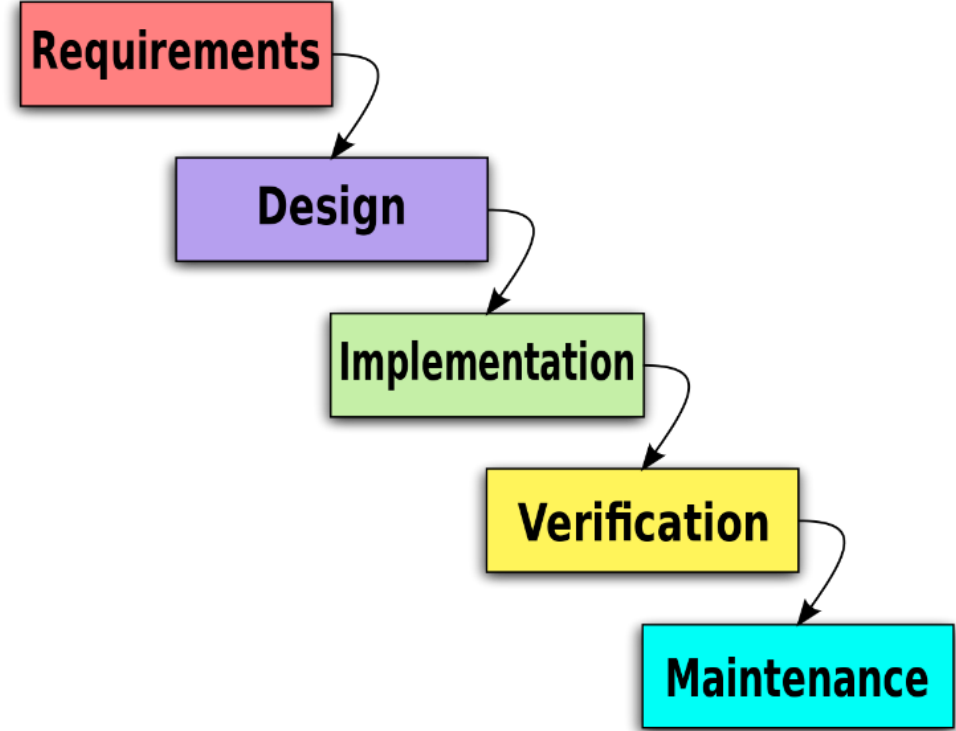

Figure 1. Waterfall Model 


\subsubsection{Requirement}

System analysis is the most needed stage to do a plan. At this stage analyze any data obtained so that it can determine the system to be built [11].

\subsubsection{Design}

This process focuses on developing a customized view with the data that has been collected. In this design, the author uses figma as a medium for designing the interface [13].

\subsubsection{Implementation}

At this stage the author implements the results of the previous design into a programming language. The language that the author uses in making this design is a programming language (PHP: Hypertext Pre-processor) and uses CodeIgniter as a framework.

\subsubsection{Verification}

After all the designs have been successfully made. Then it will be tested for each of its features. Testing is done by means of Blackbox testing. This test intends to find out whether every feature in the system can function properly and correctly.

\subsubsection{Maintenance}

Maintenance is the stage where the program is run by and at the user's place, maintenance is carried out to find out errors that were not found in the previous stage.

\subsection{System Analysis}

\subsubsection{UML (Unidied Modeling Language)}

At this design stage, the researcher uses a design tool, namely the UML diagram. UML is a system design model that has the advantage of being able to facilitate system developers in designing the system to be created because of its object-oriented nature [14]. Understanding Unified Modeling Language (UML) according to Adi Nugroho (2009:4) UML is a collaborative methodology between Booch methods, Object Modeling Technique (OMT), and ObjectOriented Software Engineering (OOSE) and several other methods. is often used today for the analysis and design of object-oriented programming languages [15]. UML is an object-oriented visual standardization tool. UML consists of grouping diagrams, namely use case diagrams, activity diagrams, sequence diagrams and class diagrams.

\subsubsection{CodeIgniter}

Codeigniter is an open-source web application or framework using the PHP programming language. The goal is to make it easier for developers to create structured code for an application by providing many libraries that can be used. Codeigniter is built on the MVC (Model, View, Controller) method which is a series of logic implemented in separate software to minimize repetitive code writing. The model relates directly to the database to process data such as insert, edit, delete. As well as validating on the controller section. View is a logical structure that is directly displayed to the user like html and css, the view is related to the controller for every processing decision. Controllers are associated with views and models that are useful for processing each user request [16].

\subsubsection{PHP (PHP: Hypertext Pre-processor)}

PHP (PHP: Hypertext Pre-processor) is one of the widely used programming languages that runs on a web server and functions as a data processor on a server. [17].

\section{Results and Discussion}

\subsection{Process Management}

Based on the results of the analysis and research that has been done, the author succeeded in getting specifications for the incoming and outgoing mail management information system to be made. In this system there are 2 actors, namely the sub-district head and the archive staff, which for each task will be shown in the picture diagram 2. Use case diagram. 


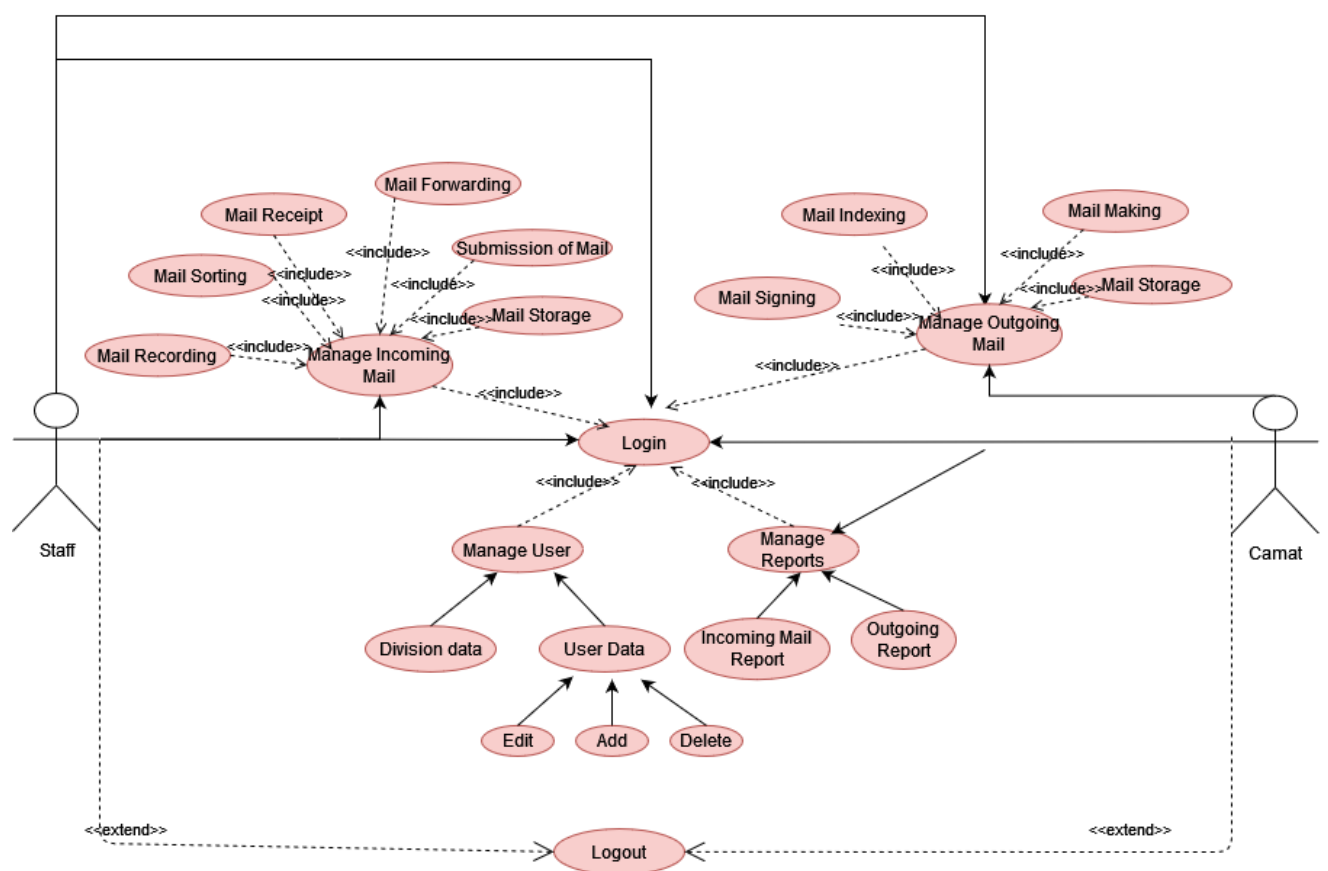

Figure 2. Usecase

Ficture 2. shows the interaction process between actor 1 and actor 2 where the staff becomes the main entity in which will interact directly with the system using the procedure for receiving incoming and outgoing Mail as follows.

\subsubsection{Incoming Mail Management}

The procedure for managing incoming mail can be done in the following ways

a. Mail Receipt

The officer who receives the letter will collect the letter and count the letter, then see if the letter matches the delivery address which will then classify the Mail based on the type of research and sign the proof of delivery as a sign that the letter has been received.

b. Mail Sorting

Sorting is the classification of Mail based on the nature of Mail such as Mail that are personal, ordinary, and confidential which will then separate the Mail for further management.

c. Mail Recording

After the letter is received and sorted according to the nature of the letter. Then the next step is to record every incoming letter in a large agenda book (daily incoming agenda) in which each incoming letter will be recorded and given an incoming mail agenda number.

d. Mail Forwarding

Incoming Mail will be submitted to the leadership, which in this case is Mr. Camat, to validate that the letter has been submitted to the leadership and the leadership is aware of the existence of the letter.

e. Submission of Mail

Submission of Mail or distribution of Mail is carried out by staff in the division to which the letter is addressed and after completion, the majib division staff returns the letter to the archive staff.

f. Mail Storage

Mail storage is carried out by archive staff in accordance with applicable regulations using the archiving method applicable at the office.

The following is the flow of the process of receiving incoming mail 


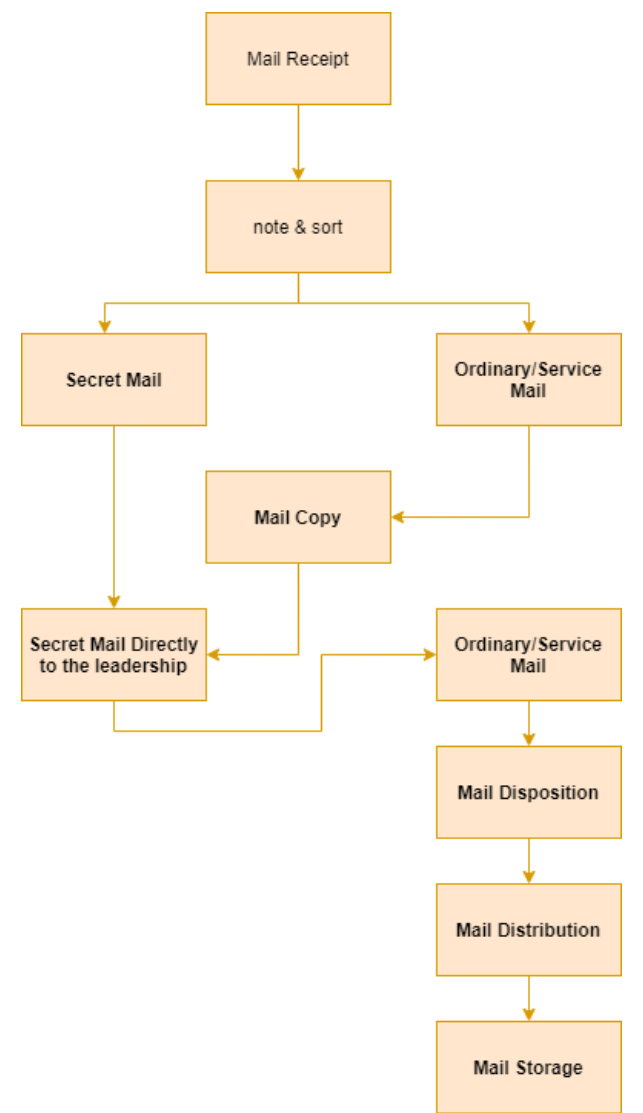

Information:

Figure 3. Inbox Flow

1. The incoming letter will be received by the staff in the general and staffing section for further sorting based on the nature of the ordinary Personal/Service letter, a copy will be made. Meanwhile, the secret letter will be directly addressed to the leadership

2. All incoming Mail after being opened (not secret Mail) will be submitted to the leadership as a report and will usually be affixed in the position at the bottom right of the letter.

3. The regular/office letter will be returned to the staff for further disposition of the letter using a disposition sheet in the form of, disposition address, purpose of disposition, content and date of disposition made by the leadership.

4. After the letter is disposed of, the letter will be distributed to the disposition address (destination of the letter) after the letter has been processed by the designated department, the letter will be returned to the archive staff.

5. Furthermore, the letter will be written in the archive book and will then be stored in the appropriate folder.

\subsubsection{Outgoing Mail Management}

The procedure for managing incoming mail can be done in the following ways

1. Mail making

Mail is written by each division based on the importance of the letter. The typed letter is conveyed to the division leader to be validated that there are no typing errors and is in accordance with the concept

2. Mail Indexing

Mail that has been typed will be brought to the general and staffing division for further writing in the daily agenda book and then an index number for the daily agenda of outgoing Mail will be given.

3. Signing Letter 
After the letter gets the index value, the foreign exchange will face the management to get a signature and stamp it to validate that the letter was really issued by the office.

4. Mail Storage

The letter that has been signed by the leadership and given a stamp will then be reproduced by 1 sheet to be stored in the archive.

\subsection{Implementasi System}

At this stage the researcher has succeeded in designing a web-based management information system for incoming and outgoing mail in the Rancaekek sub-district that can manage mail effectively and efficiently.

\subsubsection{Interface System}

\section{Login Pegawai}

\section{No Induk Pegawai}

Masukan Nomor Induk Pegawai...

\section{Password}

\section{password}

\section{Show Password}

\section{Login}

Figure 4. Login Page

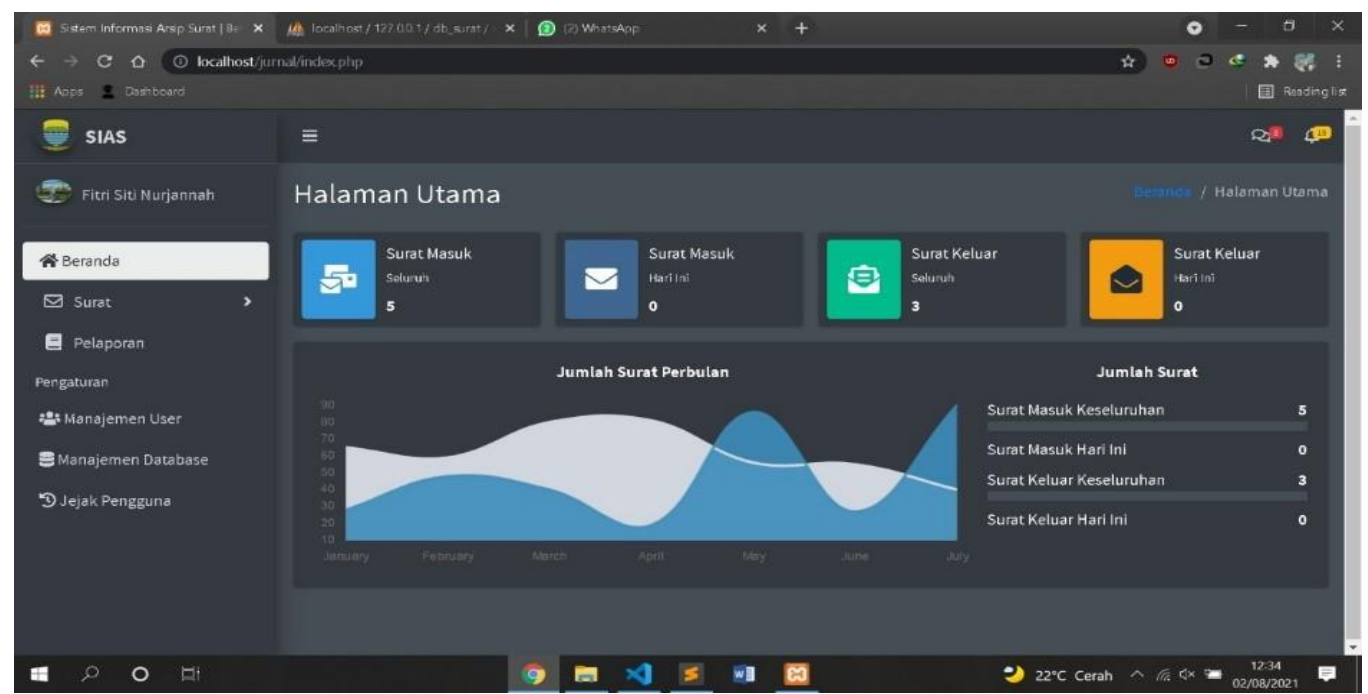

Figure5. Main page view of incoming and outgoing mail management 


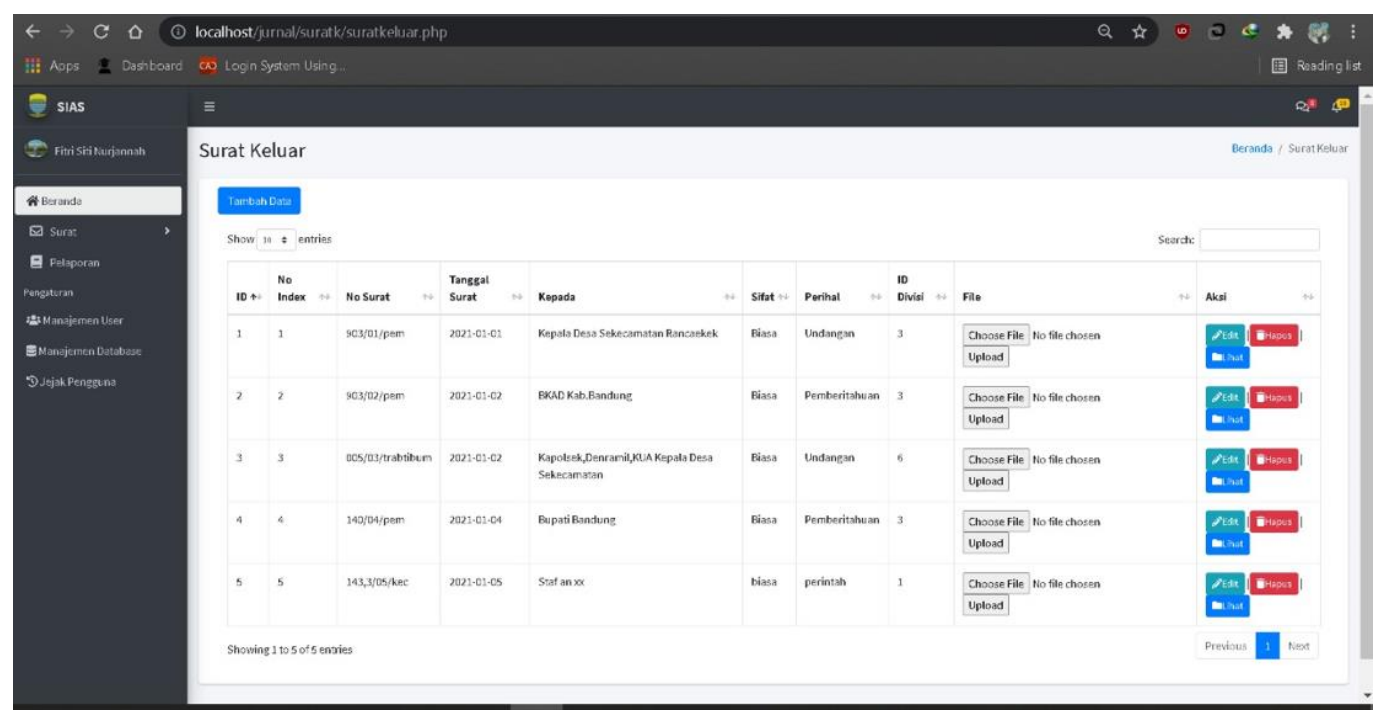

Figure 6. Incoming mail page

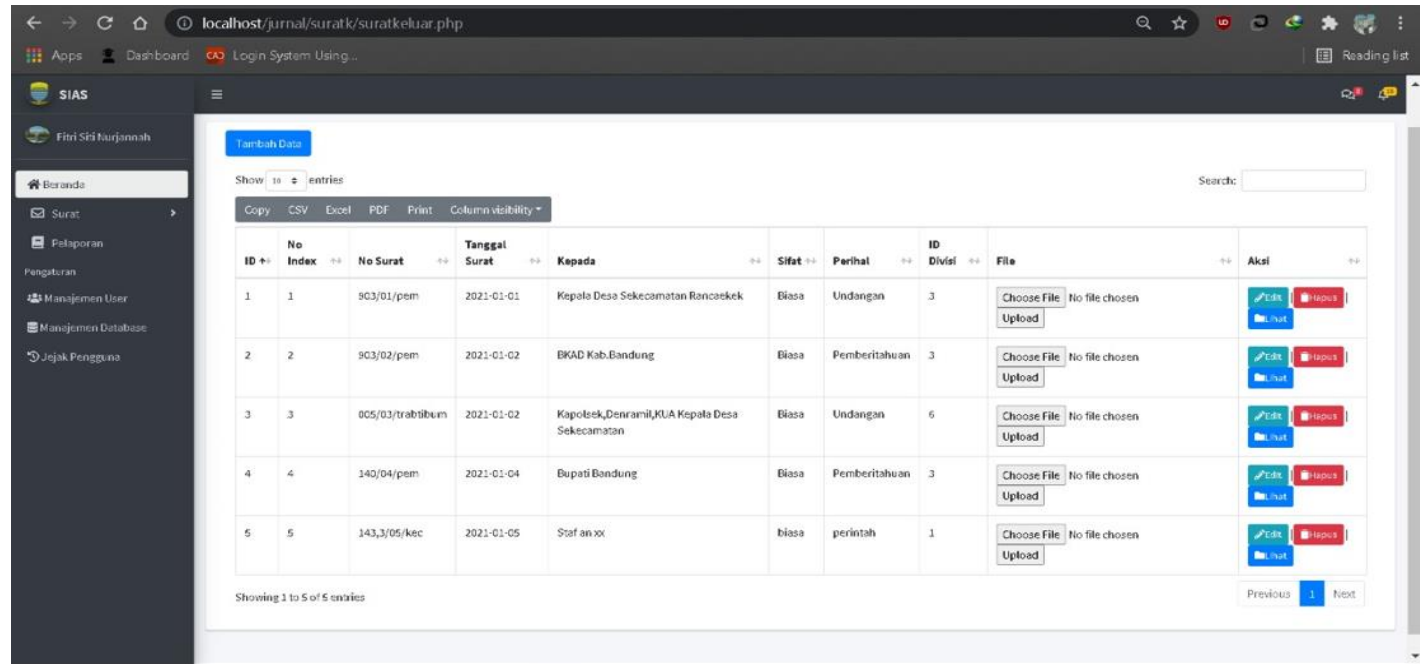

Figure 7. Outgoing mail page

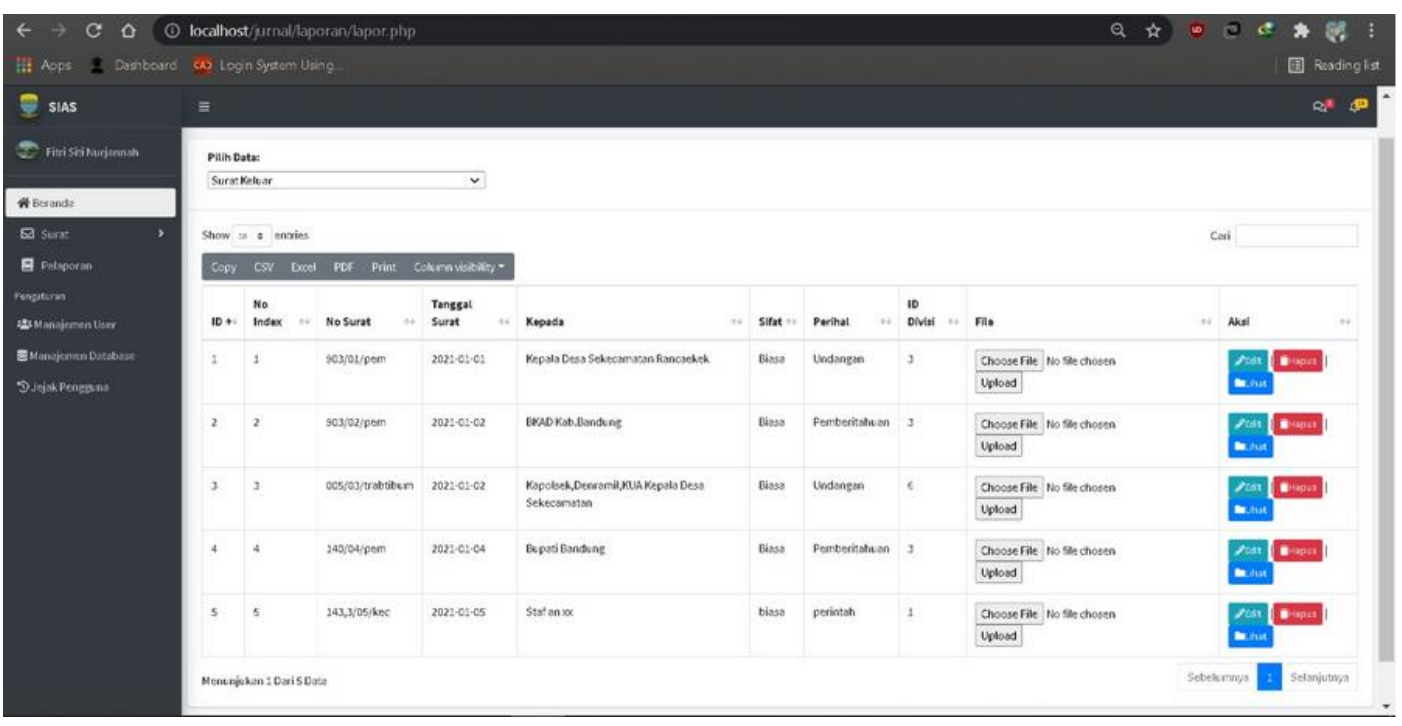


Figure 8. Report page

Sistem Informasi Arsip Surat | Surat Keluar

\begin{tabular}{|c|c|c|c|c|c|c|c|}
\hline ID & $\begin{array}{l}\text { No } \\
\text { Index }\end{array}$ & No Surat & $\begin{array}{l}\text { Tanggal } \\
\text { Surat }\end{array}$ & Kepada & Sifat & Perihal & $\begin{array}{l}\text { ID File } \\
\text { Divisi }\end{array}$ \\
\hline 1 & 1 & $\begin{array}{l}\text { 903/01/ } \\
\text { pem }\end{array}$ & 2021-01-01 & $\begin{array}{l}\text { Kepala Desa Sekecamatan } \\
\text { Rancaekek }\end{array}$ & Biasa & Undangan & 3 \\
\hline 2 & 2 & $\begin{array}{l}903 / 02 / \\
\text { pem }\end{array}$ & 2021-01-02 & BKAD Kab.Bandung & Biasa & Pemberitahuan & 3 \\
\hline 3 & 3 & $\begin{array}{l}005 / 03 / \\
\text { trabtibum }\end{array}$ & 2021-01-02 & $\begin{array}{l}\text { Kapolsek,Denramil,KUA } \\
\text { Kepala Desa Sekecamatan }\end{array}$ & Biasa & Undangan & 6 \\
\hline 4 & 4 & $\begin{array}{l}140 / 04 / \\
\text { pem }\end{array}$ & 2021-01-04 & Bupati Bandung & Biasa & Pemberitahuan & 3 \\
\hline 5 & 5 & $\begin{array}{l}143,3 / 05 / \\
\text { kec }\end{array}$ & 2021-01-05 & Staf an $\mathrm{xx}$ & biasa & perintah & 1 \\
\hline
\end{tabular}

\subsection{System Test}

Figure 9. PDF Export Page

\subsubsection{Black Box Testing}

The system test uses black box testing, which is a test that focuses on the functional system when the system is run which aims to find errors and can immediately resolve errors found [6].

Table 1. Test result

\begin{tabular}{|c|c|c|c|c|c|}
\hline No & $\begin{array}{c}\text { Test } \\
\text { Descripti } \\
\text { on }\end{array}$ & Testing Scenario & Expected results & Test Results & Conclusion \\
\hline \multirow[t]{5}{*}{1} & \multirow[t]{5}{*}{ Login } & $\begin{array}{l}\text { Enter a blank NIP } \\
\text { and password }\end{array}$ & $\begin{array}{l}\text { NIP and password } \\
\text { notifications } \\
\text { cannot be empty }\end{array}$ & $\begin{array}{l}\text { NIP and } \\
\text { password } \\
\text { notifications } \\
\text { cannot be } \\
\text { empty }\end{array}$ & $\begin{array}{l}\text { According to } \\
\text { expectations }\end{array}$ \\
\hline & & $\begin{array}{l}\text { Enter wrong NIP } \\
\text { and wrong } \\
\text { password }\end{array}$ & Back to login & $\begin{array}{l}\text { Back to login } \\
\text { with notifikasi } \\
\text { check your } \\
\text { NIP/Password }\end{array}$ & $\begin{array}{l}\text { According to } \\
\text { expectations }\end{array}$ \\
\hline & & $\begin{array}{l}\text { Enter correct NIP } \\
\text { and wrong } \\
\text { password }\end{array}$ & $\begin{array}{l}\text { Notifications } \\
\text { check your NIP } \\
\text { and password }\end{array}$ & $\begin{array}{l}\text { Notifications } \\
\text { check your NIP } \\
\text { and password }\end{array}$ & $\begin{array}{l}\text { According to } \\
\text { expectations }\end{array}$ \\
\hline & & $\begin{array}{l}\text { Enter wrong NIP } \\
\text { and correct } \\
\text { password }\end{array}$ & $\begin{array}{l}\text { Notifications } \\
\text { check your NIP } \\
\text { and password }\end{array}$ & $\begin{array}{l}\text { Notifications } \\
\text { check your NIP } \\
\text { and password }\end{array}$ & $\begin{array}{l}\text { According to } \\
\text { expectations }\end{array}$ \\
\hline & & $\begin{array}{l}\text { Enter the correct } \\
\text { NIP and password }\end{array}$ & $\begin{array}{l}\text { Go to dashboard } \\
\text { page }\end{array}$ & $\begin{array}{l}\text { Go to } \\
\text { dashboard page }\end{array}$ & $\begin{array}{l}\text { According to } \\
\text { expectations }\end{array}$ \\
\hline \multirow[t]{2}{*}{2} & \multirow[t]{2}{*}{$\begin{array}{l}\text { Incoming } \\
\text { mail }\end{array}$} & $\begin{array}{l}\text { Enter everything } \\
\text { except the letter } \\
\text { number }\end{array}$ & $\begin{array}{l}\text { The letter number } \\
\text { notification cannot } \\
\text { be empty }\end{array}$ & $\begin{array}{l}\text { The letter } \\
\text { number } \\
\text { notification } \\
\text { cannot be } \\
\text { empty }\end{array}$ & $\begin{array}{l}\text { According to } \\
\text { expectations }\end{array}$ \\
\hline & & $\begin{array}{l}\text { Enter everything } \\
\text { except the date of } \\
\text { the letter }\end{array}$ & $\begin{array}{l}\text { Letter date } \\
\text { notification cannot } \\
\text { be empty }\end{array}$ & $\begin{array}{l}\text { Letter date } \\
\text { notification } \\
\text { cannot be }\end{array}$ & $\begin{array}{l}\text { According to } \\
\text { expectations }\end{array}$ \\
\hline
\end{tabular}




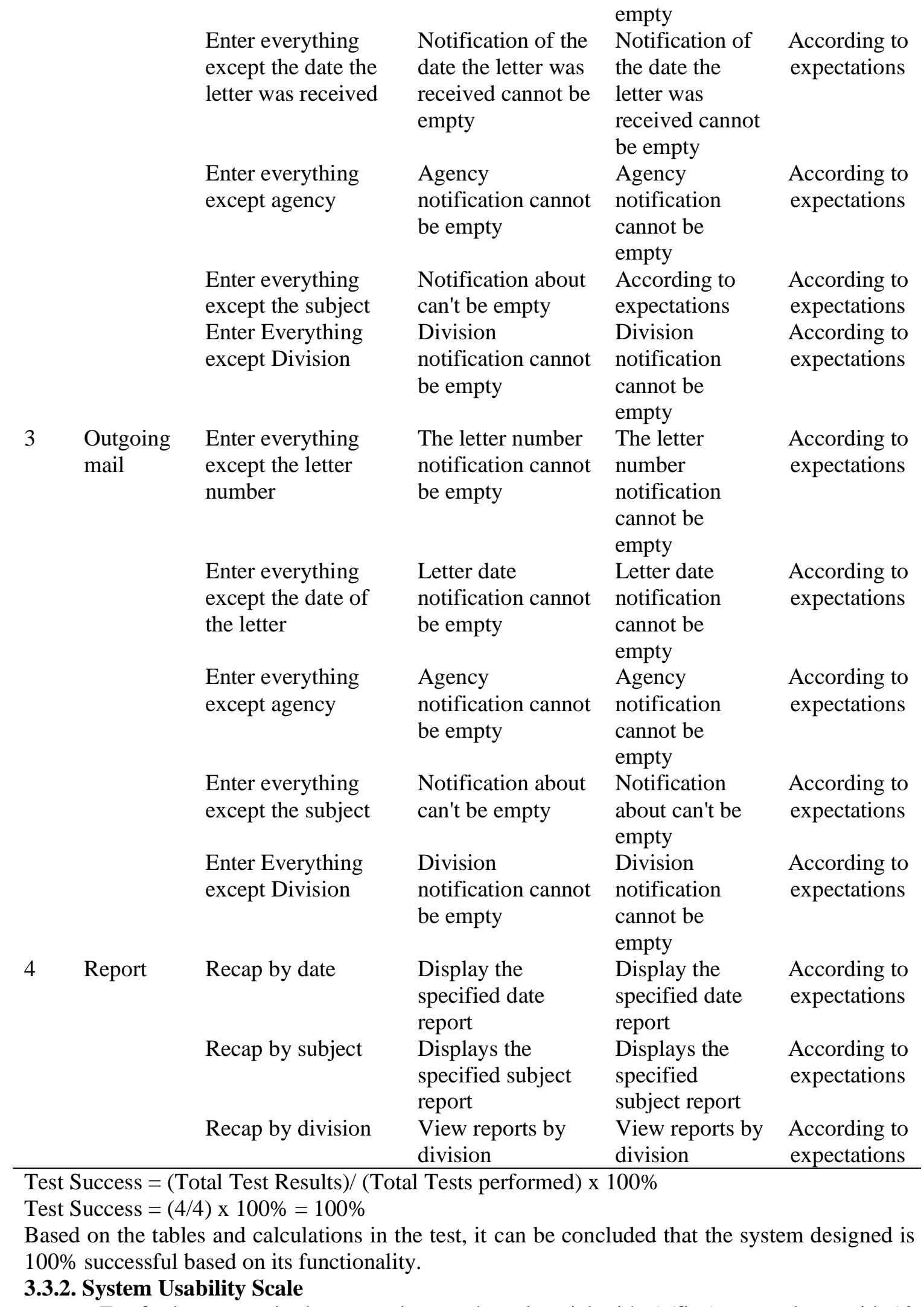

For further research, the researcher conducted a trial with 5 (five) respondents with 10 (ten) questions consisting of 5 (five) positive questions and 5 (five) negative questions with a 5 point value scale. SUS (Syetem Usability Scare) has the following conditions [18].

a. For odd number questions, the value obtained is the position of the scale minus 1 
b. For even number questions, the value obtained is the position of the scale minus 5

Table 2. Skala score

\begin{tabular}{cc}
\hline Options & Skor \\
\hline Strongly agree & 1 \\
Do not agree & 2 \\
Neutral & 3 \\
Agree & 4 \\
Strongly agree & 5 \\
\hline
\end{tabular}

And the interrupt values will be explained in the following table

Table 3. Interupsi SUS score

\begin{tabular}{cccccc}
\hline \multicolumn{2}{c}{\begin{tabular}{c} 
ACCEPTABILITY \\
\multicolumn{2}{c}{ RANGES }
\end{tabular}} & \multicolumn{2}{c}{ GRADE SCALE } & \multicolumn{2}{c}{ ADJECTIVE RATINGS } \\
\hline $\begin{array}{c}\text { Acceptable } \\
\text { High }\end{array}$ & $62-100$ & A & $91-100$ & 100 & Best Imaginable \\
$\begin{array}{c}\text { Acceptable } \\
\text { Low }\end{array}$ & $49-61$ & B & $81-90$ & 85 & Excellent \\
Not & $0-60$ & C & $71-80$ & 72 & Good \\
Acceptable & & D & $61-70$ & 52 & Fair \\
& & E & $0-60$ & 38 & Poor \\
& & & & 25 & Worst Imaginable \\
\hline
\end{tabular}

Table 4. Score Calculation Results

Calculation Result Score

\begin{tabular}{cccccccccccccc} 
No & $\begin{array}{c}\text { Respon } \\
\text { dent }\end{array}$ & Q1 & Q2 & Q3 & Q4 & Q5 & Q6 & Q7 & Q8 & Q9 & Q10 & Results & Score \\
\hline 1 & R1 & 4 & 4 & 4 & 2 & 3 & 4 & 3 & 4 & 3 & 4 & 35 & 88 \\
2 & R2 & 4 & 4 & 4 & 4 & 3 & 2 & 4 & 1 & 4 & 3 & 34 & 85 \\
3 & R3 & 4 & 3 & 4 & 2 & 4 & 1 & 3 & 2 & 4 & 2 & 29 & 73 \\
4 & R4 & 4 & 3 & 3 & 4 & 4 & 4 & 3 & 3 & 4 & 3 & 35 & 88 \\
5 & R5 & 4 & 4 & 4 & 1 & 3 & 3 & 4 & 2 & 3 & 4 & 32 & 80 \\
& \multicolumn{11}{c}{ Result Average SUS Score } \\
\hline
\end{tabular}

Description

- $\quad$ R1-R5 = Respondent

- Q1-Q5 = Question

- $\quad$ Results $=$ odd scale value -1 , even scale value -5

- $\quad$ Score $=$ Result X 2.5

- $\quad$ Average $=$ total score/number of respondents

Referring to table 4, the results of the test using the SUS (Syetem Usability Scare) method show that this incoming and outgoing mail management information system has an average score of 82.5 which includes an acceptable high score with a grade B and adjective rants in the almost excellent category.

Based on the research conducted, the researcher concludes that this research is in line with previous research studies, if in previous studies many researchers focused on storing Mail, it is unfortunate because in this study the researchers determined that in addition to this system being able to store Mail in the form of files, this system can also store Mail in the form of files. distribute mail. the Information System for Incoming and Outgoing Mail Management in Rancaekek District has several advantages over previous research including

1. The number of Mail can be viewed by day, date, month and year

2. Mail are made in chart diagrams to facilitate reporting 
3. There is a real-time notification feature for incoming mail in each division

4. Track record feature to minimize system sabotage errors.

\section{Conclusion}

The research method using the waterfall system makes this system more structured and has fewer errors. The management of Mail that were previously carried out by the Rancaekek sub-district still uses manuals and the distribution of unstructured Mail can now be handled by the system that has been created. in this system the distribution of Mail can be directly distributed by the system by means of the staff who receive the letter will input the letter into the system for further viewing by the staff of the respective division intended.

The archive staff who receives the letter will input the incoming letter into the system, the division to which the letter is addressed will receive an incoming message notification, for further confirmation. The information provided in real-time of course makes it easier for archival staff and functional staff.

In addition to the letter notification in this study, the researchers also found a track recoad feature where every activity carried out by archive staff, functional staff and sub-district head will be recorded for each step, the poll is (Name, Date, Time, and what was done). This feature is very effective when there are strangers who access and sabotage the system it will be seen very clearly.

Based on the results of the tests carried out by means of black box testing and testing using the SUS (sus) method.

According to the results of the black box testing system, the success of the test produces a test value of $100 \%$ which indicates that the system has worked as a whole without any errors or errors. based on the SUS test, it can be said that the average test score given by the respondents is 82.5 points or in the vulnerable percentage that is $70 \%-80 \%$. which 82.5 points are included in Acceptable High which gets a grade scale (B) with Adjective Rantings Almost Excellent,

\section{Bibliography}

[1] Kecamatan Rancaekek - Kabupaten Bandung.” https://kecamatanrancaekek.bandungkab.go.id/ (accessed Jul. 24, 2021).

[2] S. Hidayat and U. Jumiatun, "Prosedur Pengelolaan Surat Untuk Memperlancar Proses Penyampaian Informasi Pada Kantor Kecamatan Pamulang," Sekretari, vol. 3, no. 1, p. 33, 2017, doi: 10.32493/skr.v3i1.637.

[3] A. E. Sawitri and A. Irhandayaningsih, "Analisis Penggunaan Aplikasi Tata Surat Dalam Pengelolaan Surat Masuk Dan Surat Keluar Pada Dinas Kesehatan Provinsi Jawa Tengah,” J. Ilmu Perpust., vol. 6, no. 3, pp. 411-420, 2017, [Online]. Available: https://ejournal3.undip.ac.id/index.php/jip/article/view/23173.

[4] A. Darlianto and I. Permana, "Sistem Informasi Pencatatan Surat Masuk," J. Rekayasa dan Manaj. Sist. Inf., vol. 2, no. 1, pp. 37-43, 2016.

[5] A. Nouvel and R. Indriani, "Informasi Surat Masuk Dan Surat Keluar Berbasis Web Pada Suatu Instansi," vol. 7, no. 1, pp. 55-62, 2021.

[6] Y. Irawan, "Aplikasi, Surat Aplikasi pengelolaan arsip surat masuk dan surat keluar pada badan perencanaan pembangunan daerah (bappeda) kota pekanbaru," J. Ilmu Komput., vol. 7, no. 2, pp. 58-63, 2019, doi: 10.33060/jik/2018/vol7.iss2.111.

[7] W. Witanti, S. Y. Pinasty, and I. V. Saputri, "Sistem Informasi Pengarsipan Surat Masuk Dan Surat Keluar Berbasis Web di kecamatan Batujajar," Semin. Nas. Din. Inform. 2020 Univ. PGRI Yogyakarta Pelaks., pp. 138-142, 2020.

[8] I. Rafidah, "Sistem Informasi Pengelolaan Surat Masuk Dan Surat Keluar Di Kecamatan Ngemplak," 2019, [Online]. Available: https://dspace.uii.ac.id/handle/123456789/14539.

[9] S. Awwaabiin, "Metode Penelitian Kualitatif: Pengertian Menurut Ahli, Jenis-Jenis, dan Karakteristiknya," penerbitdeepublish.com. https://penerbitdeepublish.com/metodepenelitian-kualitatif/. 
[10] Syafnidawaty, "Penelitian kualitatif," Universitas Raharja, 2020. https://raharja.ac.id/2020/10/29/penelitian-kualitatif/.

[11] S. Salamun and D. Arisandi, "Sistem Monitoring Kinerja Dosen Pada Institusi Perguruan Tinggi Swasta (Studi Kasus: Universitas Abdurrab)," Digit. Zo. J. Teknol. Inf. dan Komun., vol. 11, no. 2, pp. 198-208, 2020, doi: 10.31849/digitalzone.v11i2.4304.

[12] Syafnidawaty, "Metode Waterfall," Univ. Raharja, 2020.

[13] R. Pramudita, R. W. Arifin, A. N. Alfian, N. Safitri, and S. D. Anwariya, "Penggunaan Aplikasi Figma Dalam Membangun Ui / Ux Yang Interaktif Pada Program Studi Teknik," J. Buana Pengabdi., vol. 3, no. 1, pp. 149-154, 2021.

[14] M Teguh Prihandoyo, "Unified Modeling Language (UML) Model Untuk Pengembangan Sistem Informasi Akademik Berbasis Web," J. Inform. J. Pengemb. IT, vol. 3, no. 1, pp. 126-129, 2018.

[15] F. Abdussalaam and M. Mardiansyah Ramadhan, "Perancangan sistem informasi work orderdengan metode iteratif menggunakan framework codeigniter (Studi Kasus :CV Sirna Miskin Bandung)," J. E-Komtek, vol. 3, no. 1, pp. 35-48, 2019, doi: 10.37339/ekomtek.v3i1.129.

[16] S. K. Heru Sulistiono, Coding Mudah dengan CodeIgniter, JQuery, Bootstrap, dan Datatable - Heru Sulistiono, S.Kom., M.Kom. - Google Buku. Elex Media Komputindo , 2018.

[17] A. Mubarak, "Rancang Bangun Aplikasi Web Sekolah Menggunakan Uml (Unified Modeling Language) Dan Bahasa Pemrograman Php (Php Hypertext Preprocessor) Berorientasi Objek," JIKO (Jurnal Inform. dan Komputer), vol. 2, no. 1, pp. 19-25, 2019, doi: 10.33387/jiko.v2i1.1052.

[18] B. Pudjoatmodjo and R. Wijaya, "Tes Kegunaan (Usability Testing) Pada Aplikasi Kepegawaian Dengan Menggunakan System Usability Scale,” Semin. Nas. Teknol. Inf. dan Multimed. 2016, pp. 37-42, 2016.

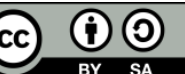

